\title{
Garlic for arterial hypertension and hypercholesterolemia Review of literature and clinical studies
}

\author{
Stanisław Surma ${ }^{1,2}$ (D), Monika Romańczyk ${ }^{1}$ (D), Maciej R. Czerniuk ${ }^{3}$ (D), Krzysztof J. Filipiak ${ }^{4}$ (D) \\ ${ }^{1}$ Faculty of Medical Sciences in Katowice, Medical University of Silesia in Katowice, Poland \\ ${ }^{2} \mathrm{Club}$ of Young Hypertensiologists, Polish Society of Hypertension \\ ${ }^{3}$ Department of Dental Surgery, Medical University of Warsaw, Poland \\ ${ }^{4}$ Institute of Clinical Sciences, Maria Sklodowska-Curie Medical Academy, Warsaw, Poland
}

\begin{abstract}
Garlic is a widely known and widely used plant. Due to its taste, it is used in the preparation of many dishes. Garlic is also used in the treatment of bacterial, viral, fungal and parasitic infections. There are many chemical compounds in garlic, but those responsible for its health-promoting effect include, first of all, those containing sulfur. These compounds are characterized by many mechanisms of action, such as antioxidant, cardioprotective and anti-inflammatory effects. Many mechanisms of action of organosulfur compounds influencing the regulation of blood pressure and lipid metabolism have been demonstrated. Many clinical studies and meta-analyses are assessing the effect of garlic on blood pressure and lipid profile in various groups of patients in the literature. This article aims to present the current knowledge on the influence of garlic on blood pressure and lipid metabolism.
\end{abstract}

Key words: garlic, blood pressure, lipids, arterial hypertension, hypercholesterolemia

Folia Cardiologica 2021; 16, 5: 296-302

\section{Hypertension and hypercholesterolemia in Poland}

Hypertension and hypercholesterolemia are the most common factors of cardiovascular risk in Poland. According to the WOBASZ II (Wieloośrodkowe Badanie Stanu Zdrowia Ludności, Multicentre Study of Population health), the prevalence of hypertension among adult Poles is $42.7 \%$, while that of hypercholesterolemia is $67.2 \%[1,2]$. In addition, the WOBASZ II study revealed that $34.6 \%$ of patients suffer from both hypertension and hypercholesterolemia [3].

Such a high prevalence and concomitance of hypertension and hypercholesterolemia stems from, among other things, insufficient social awareness regarding the impact of an unhealthy lifestyle on cardiovascular function $[4,5]$. Numerous studies have shown that dietary habits have a significant impact on blood pressure and plasma lipid levels [6-8].

This paper aims to present current biochemical and clinical knowledge on the impact of commonly consumed garlic and garlic supplements on blood pressure and lipid concentration in plasma.

\section{Garlic - characteristics, properties and differences}

Garlic (Allium L.) belongs to the Amaryllidaceae family and is among the oldest plants cultivated by man, not only due to its culinary value, but also medicinal properties. Garlic comes from Asia and has been known for approximately 5,000 years. Ancient documents from Egypt, Greece, Rome, China and India confirm that garlic was used in medicine [9]. Currently, garlic and its supplements are used to treat

Address for correspondence: Professor Krzysztof J. Filipiak MD, PhD, FESC, Instytut Nauk Klinicznych, Uczelnia Medyczna im. Marii Skłodowskiej-Curie w Warszawie, Pałac Lubomirskich, Plac Żelaznej Bramy 10, 00-136 Warszawa, Poland, e-mail: krzysztof.filipiak@uczelniamedyczna.com.pl

This article is available in open access under Creative Common Attribution-Non-Commercial-No Derivatives 4.0 International (CC BY-NC-ND 4.0) license, allowing to download articles and share them with others as long as they credit the authors and the publisher, but without permission to change them in any way or use them commercially. 


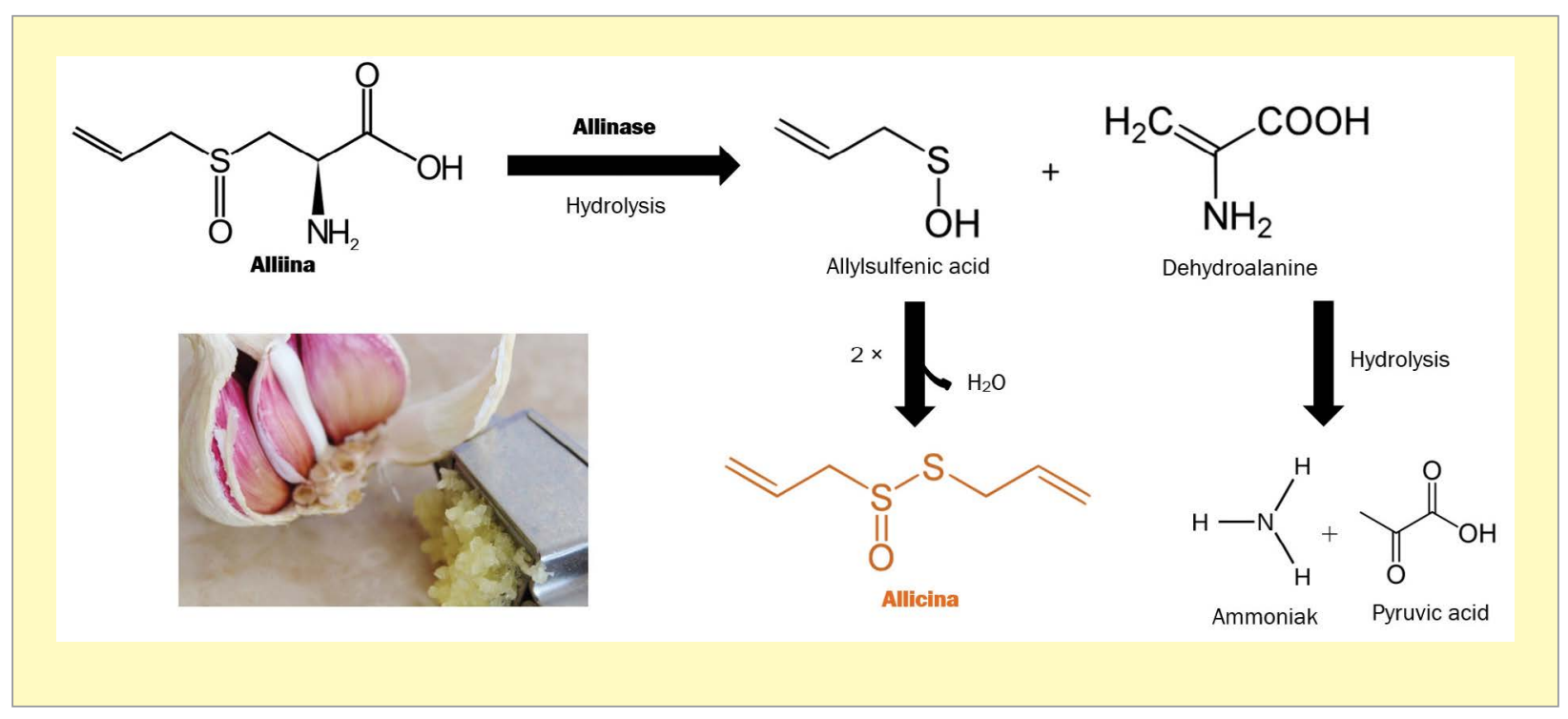

Figure 1. Formation of allicin from alliin by the enzyme alliinase

or support the treatment of bacterial, viral, fungal and parasitic infections [9].

Garlic is a vegetable that is commonly imported to Poland. According to the data of Statistics Poland (GUS, Główny Urząd Statystyczny), garlic imports to Poland amounted to 11,600 tonnes, and its value reached PLN 72.4 million. The data indicate that the largest amounts of garlic were imported from Spain, Egypt, China and Portugal.

Fresh garlic contains water (62-68\%), carbohydrates (26-30\%), proteins (1.5-2.1\%), amino acids (1-1.5\%), organosulfur compounds (1.1-3.5\%), and fibre (1.5\%) [10]. The health-promoting properties of garlic are primarily attributed to the organic sulfur compounds that it contains. The best-studied biologically active organosulfur compounds in garlic are diallyl disulfide, diallyl trisulfide, methyl diallyl trisulfide, S-allyl cysteine, and alliin [10]. It should be mentioned that the chemical composition of garlic changes when it is processed. The most important chemical reaction that occurs, for example, during the crushing of garlic cloves is the production of allicin from alliin under the influence of the enzyme alliinase (EC 4.4.1.4) (Figure 1). It is worth mentioning that allicin is responsible for the characteristic smell of crushed garlic cloves [11].

The organosulfur compounds found in garlic have numerous health-promoting properties, such as antioxidant (especially strong due to their chemical structure), cardioprotective, antimicrobial, and anti-inflammatory activity [11]. It should be mentioned that garlic shows potent bactericidal activity against numerous Gram (+) and Gram (-) microorganisms, including antibiotic-resistant strains [12]. The exact biochemical mechanism of action of organosulfur compounds found in garlic is presented in Figure 2.
Since garlic is grown in many climatic zones and thus is exposed to different environmental factors, its different varieties (e.g., Polish garlic "Harnaś", Chinese and Portuguese garlic, Spanish garlic "Violetta" or Italian garlic "white or savoury") may differ not only in terms of their morphology but also in terms of the content of biologically active substances, which may translate into their biological properties. Rybczynska et al. [13] used an in vitro culture of human vascular endothelial cells (HUVEC) to investigate the impact of Polish and Chinese garlic extracts on the expression of adhesive molecules - soluble vascular cell adhesion molecule 1 (sVCAM-1), soluble intercellular adhesive molecule 1 (sICAM-1) as well as the expression of metalloproteinases ADAM10 (ADAM metallopeptidase domain 10) and ADAM 17 (ADAM metallopeptidase domain 17) in these cells. It was demonstrated that extracts from both varieties of garlic reduced the expression of these proteins, with the extract from the Chinese variety showing a stronger effect [13]. Furthermore, Matysiak et al. [14] demonstrated that chemical substances contained in the aqueous extract from Chinese garlic had a greater ability to neutralize the DPPH free radical, cation radical ABTS+ and chelated copper (II) ions. They also inhibited the growth of the Saccharomyces cerevisiae fungi much more strongly than those contained in the aqueous extract from Polish garlic. On the other hand, chemical substances contained in an aqueous extract from Polish garlic chelated iron (II) ions more strongly [14]. Another study by Matysiak et al. revealed that varieties of garlic from China, Poland and Spain had different antioxidant properties [15]. Gaweł-Bęben et al. [16] also observed that among such varieties of garlic as Polish garlic "Harnaś", Chinese, Uzbek, Portuguese garlic, Spanish garlic "Violetta” 


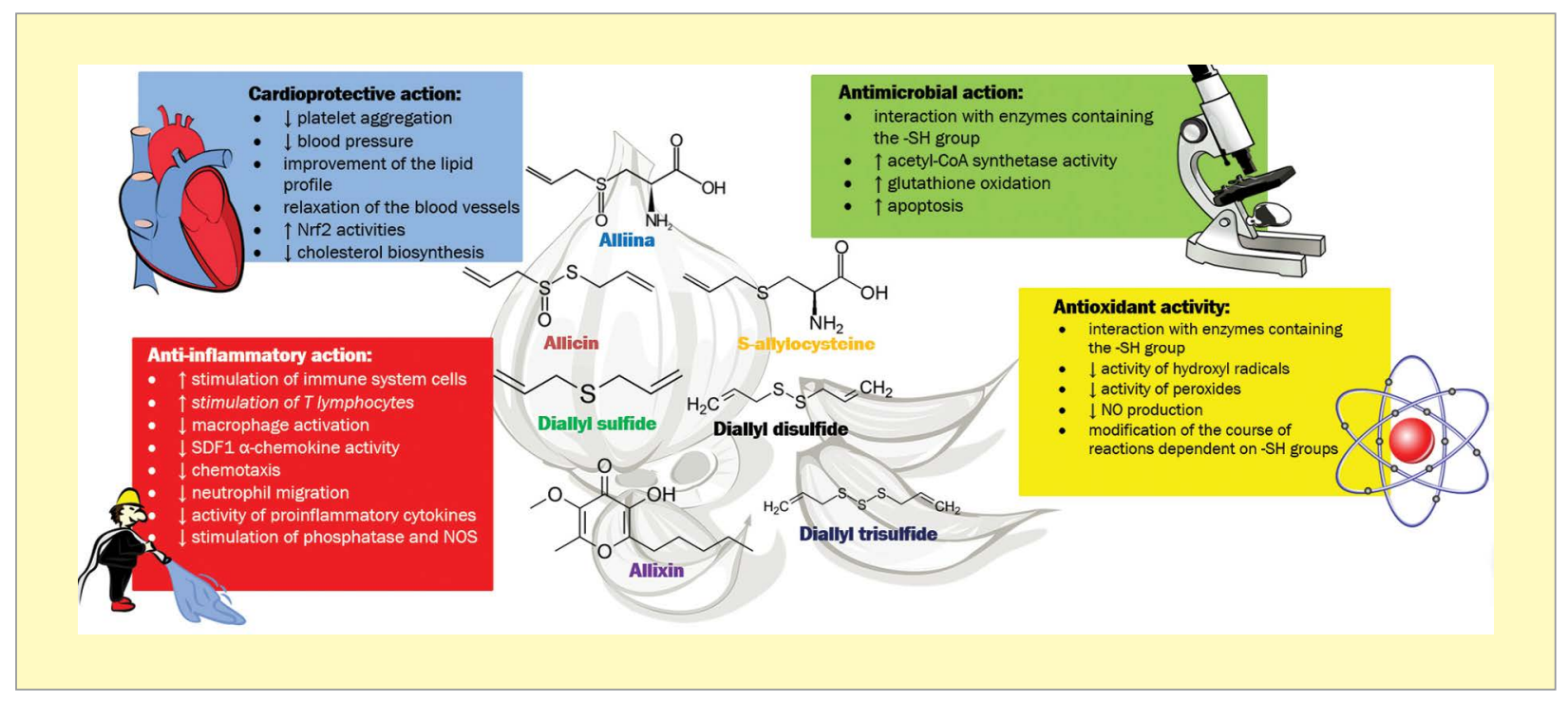

Figure 2. Effects of garlic on human health (based on [11]) Nrf2 - nuclear factor erythroid; SDF-1 - stromal cell-derived factor 1; NOS nitric oxide synthase; -SH group - thiol group

and Italian "white or savoury" garlic, it was the Italian varieties that showed the strongest antifungal effect against Saccharomyces cerevisiae. Magnetic resonance imaging (MRI) analysis of the content of organic sulfur compounds in individual garlic extracts showed that the tested varieties of garlic differed in terms of their content of biologically active compounds, such as allicin [16].

In conclusion, garlic is a popular vegetable used for both culinary and medicinal purposes. It contains many chemical compounds and its health-promoting properties are primarily attributed to organosulfur compounds, such as acillin. Different varieties of garlic originating from different geographical areas have different biological properties.

\section{Garlic for blood pressure and lipid metabolism regulation - biochemical mechanisms}

It seems that the mechanisms of the antihypertensive properties of garlic are not yet fully understood. In their review of literature, Borghi and Cicero [17] attempted to summarize the knowledge on the impact of various nutraceuticals, including garlic, on blood pressure. According to the authors, the most likely mechanisms responsible for garlic-induced lowering of blood pressure include increased production of nitrogen oxide (NO) by vascular endothelial cells, increased production of Hydrogen sulfide $\left(\mathrm{H}_{2} \mathrm{~S}\right)$, increased production of bradykinin, decreased sensitivity of tissues to catecholamines, reduced activity of the angiotensin-converting enzyme (ACE), as well as blocking of calcium channels [17].
The hypolipemic properties of garlic involve several biochemical mechanisms [11]. Chemical compounds present in garlic decrease the activity of enzymes such as fatty acid synthase, glucose-6-phosphate dehydrogenase, and 3-hydroxy-3-methyl-glutaryl-CoA reductase (HMGCoA) [18]. In addition, garlic increases the excretion of acidic and neutral steroids from the organism [19]. It is also suggested that the chemical compounds present in garlic reduced the gene expression of such enzymes as cholesterol ester transfer protein (CETP), Niemann-Pick C1-like 1 protein (NPC1L1), and microsomal triacylglyceride transfer protein (MTP) [20]. Garlic exerts positive effects on high-density lipoprotein (HDL) by regulating the ATP-binding cassette transporters, such as ABCG5, ABCG8 and ABCA1, involved in lipid transport [11].

It should also be mentioned that garlic has been demonstrated to have a positive effect on the composition of the gut microbiota. Disorders in gut microbiota may play a significant role in hypertension pathogenesis and interventions aimed at reducing dysbiosis in this region of the gut have antihypertensive effects [21, 22]. A meta-analysis conducted by Ried [23] investigated the impact of garlic on gut microbiota. It was demonstrated that there was an improvement in gut microbiota, as evidenced by greater microbial diversity, with a significant increase in the number of Lactobacillus and Clostridia species that was observed after three months of garlic supplementation [23]. In addition, biologically active compounds present in garlic show antimicrobial activity against pathogens contributing to the development of periodontitis or caries, such as Porphyromonas gingivalis, Aggregatibacter 
Table 1. Summary of results of meta-analyses $(n=7)$ investigating the effects of garlic on blood pressure

\begin{tabular}{|c|c|c|c|c|c|}
\hline Author & Year & Study & Sample size & Results & Impact on BP \\
\hline $\begin{array}{l}\text { Mulawarman } \\
\text { et al. [27] }\end{array}$ & 2021 & $\begin{array}{l}\text { Meta-analysis } \\
\text { of RCTs }\end{array}$ & $\begin{array}{l}12 \text { RCTs (503 } \\
\text { hypertensive } \\
\text { patients) }\end{array}$ & $\begin{array}{l}\text { In the group treated with garlic: } \\
\text { - SBP: reduction by } 3.62 \mathrm{~mm} \mathrm{Hg}(95 \% \mathrm{Cl}:-5.43 \\
\text { to }-1.80 \mathrm{~mm} \mathrm{Hg}, p<0.0001) \\
\text { DBP: reduction by } 1.40 \mathrm{~mm} \mathrm{Hg}(95 \% \mathrm{Cl}:-2.72 \\
\text { to }-0.08 \mathrm{~mm} \mathrm{Hg}, p=0.04)\end{array}$ & \\
\hline \multirow[t]{2}{*}{ Ried [23] } & \multirow[t]{2}{*}{2020} & \multirow[t]{2}{*}{$\begin{array}{l}\text { Meta-analysis } \\
\text { of RCTs }\end{array}$} & \multirow[t]{2}{*}{$\begin{array}{l}12 \text { RCTs (553 } \\
\text { hypertensive } \\
\text { patients) }\end{array}$} & 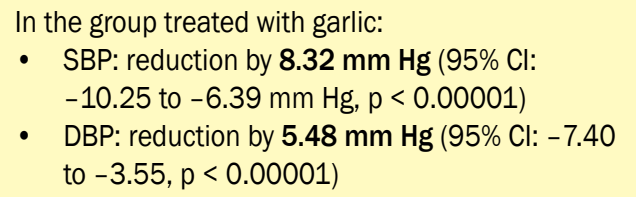 & \\
\hline & & & & $\begin{array}{l}\text { The observed BP reduction translated into lowering } \\
\text { the cardiovascular risk by } 16-40 \%\end{array}$ & \\
\hline \multirow[t]{2}{*}{ Ried [28] } & \multirow[t]{2}{*}{2016} & \multirow[t]{2}{*}{$\begin{array}{l}\text { Meta-analysis } \\
\text { of RCTs }\end{array}$} & \multirow[t]{2}{*}{$\begin{array}{l}20 \text { RCTs } \\
\text { ( } \mathrm{n}=970, \text { inclu- } \\
\text { ding hypertensi- } \\
\text { ve patients) }\end{array}$} & $\begin{array}{l}\text { In patients with hypertension: } \\
\text { - SBP: reduction by } 8.35 \mathrm{~mm} \mathrm{Hg}(95 \% \mathrm{Cl} \text { : } \\
-10.58 \text { to }-6.11 \mathrm{~mm} \mathrm{Hg}, \mathrm{p}<0.00001) \\
\text { DBP: reduction by } 6.08 \mathrm{~mm} \mathrm{Hg}(95 \% \mathrm{Cl}:-7.33 \\
\text { to }-4.48 \mathrm{~mm} \mathrm{Hg}, p<0.00001)\end{array}$ & \\
\hline & & & & $\begin{array}{l}\text { Greater antihypertensive properties were observed } \\
\text { in the case of garlic powder (compared to mature } \\
\text { garlic extract) }\end{array}$ & \\
\hline \multirow[t]{2}{*}{$\begin{array}{l}\text { Rohner et al. } \\
\text { [29] }\end{array}$} & \multirow[t]{2}{*}{2015} & \multirow[t]{2}{*}{$\begin{array}{l}\text { Meta-analysis } \\
\text { of RCTs }\end{array}$} & \multirow[t]{2}{*}{$\begin{array}{l}10 \text { RCTs ( } 482 \\
\text { hypertensive } \\
\text { patients) }\end{array}$} & 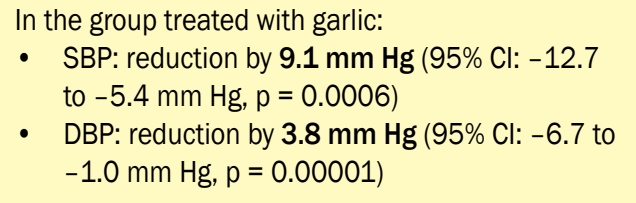 & \\
\hline & & & & $\begin{array}{l}\text { The effect varied depending on the garlic prepara- } \\
\text { tion used }\end{array}$ & \\
\hline $\begin{array}{l}\text { Wang et al. } \\
\text { [30] }\end{array}$ & 2015 & $\begin{array}{l}\text { Meta-analysis } \\
\text { of RCTs }\end{array}$ & $\begin{array}{l}17 \text { RCTs (he- } \\
\text { althy individuals } \\
\text { and individuals } \\
\text { with hyperten- } \\
\text { sion) }\end{array}$ & $\begin{array}{l}\text { Individuals with normal blood pressure: } \\
\text { - SBP: not significant } \\
\text { - DBP: not significant } \\
\text { Hypertensive patients: } \\
\text { - SBP: reduction by } 4.4 \mathrm{~mm} \mathrm{Hg}(95 \% \mathrm{Cl}:-7.37 \\
\text { to }-1.42 \mathrm{~mm} \mathrm{Hg}, \mathrm{p}=0.004) \\
\text { - DBP: not significant }\end{array}$ & \\
\hline $\begin{array}{l}\text { Xiong et al. } \\
\text { [31] }\end{array}$ & 2015 & $\begin{array}{l}\text { Meta-analysis } \\
\text { of RCTs }\end{array}$ & $\begin{array}{l}7 \text { RCTs (391 } \\
\text { hypertensive } \\
\text { patients) }\end{array}$ & $\begin{array}{l}\text { In the group treated with garlic: } \\
\text { - SBP: reduction by } 6.71 \mathrm{~mm} \mathrm{Hg}(95 \% \mathrm{Cl} \text { : } \\
-12.44 \text { to }-0.99, \mathrm{p}=0.02) \\
\text { - SBP: reduction by } 4.79 \mathrm{~mm} \mathrm{Hg}(95 \% \mathrm{Cl}:-6.60 \\
\text { to }-2.99 \mathrm{~mm} \mathrm{Hg}, p<0.00001)\end{array}$ & \\
\hline $\begin{array}{l}\text { Kwak et al. } \\
\text { [32] }\end{array}$ & 2014 & $\begin{array}{l}\text { Meta-analysis } \\
\text { of RCTs }\end{array}$ & 9/10 RCTs & $\begin{array}{l}\text { In the group treated with garlic: } \\
\text { - SBP: reduction by } 4.34 \mathrm{~mm} \mathrm{Hg}(95 \% \mathrm{Cl}:-8.38 \\
\text { to }-0.29 \mathrm{~mm} \mathrm{Hg}, p=0.036) \\
\text { DBP: reduction by } 2.36 \mathrm{~mm} \mathrm{Hg}(95 \% \mathrm{Cl}:-4.56 \\
\text { to }-0.15, p=0.036)\end{array}$ & \\
\hline
\end{tabular}

$\mathrm{RCT}$ - randomized controlled trial; SBP - systolic blood pressure; DBP - diastolic blood pressure; $\mathrm{Cl}$ - confidence interval 
Table 2. Summary of results of meta-analyses $(n=8)$ investigating the effects of garlic on lipid metabolism

\begin{tabular}{|c|c|c|c|c|c|}
\hline Author & Year & Study & Sample size & Results & Effects on lipids \\
\hline \multirow[t]{3}{*}{$\begin{array}{l}\text { Gyawali et } \\
\text { al. [33] }\end{array}$} & 2021 & $\begin{array}{l}\text { Meta- } \\
\text {-analysis } \\
\text { of RCTs }\end{array}$ & $\begin{array}{l}24 \text { RCTs ( } n=1,386 \text {, } \\
\text { including patients } \\
\text { with cardiovascular } \\
\text { risk factors) }\end{array}$ & $\begin{array}{l}\text { In the garlic use group: } \\
\text { - TC: reduction by } 12.45 \mathrm{mg} / \mathrm{dL}(95 \% \mathrm{Cl}:-18.68 \text { to } \\
-6.22 \mathrm{mg} / \mathrm{dL}, \mathrm{p}<0.00001) \\
\text { - LDL cholesterol: reduction by } 10.37 \mathrm{mg} / \mathrm{dL}(95 \% \\
\text { Cl: }-17.58 \text { to }-3.16 \mathrm{mg} / \mathrm{dL}, p=0.005)\end{array}$ & \\
\hline & & & & TG: not significant & \\
\hline & & & & HDL cholesterol: not significant & \\
\hline $\begin{array}{l}\text { Mulawar- } \\
\text { man et al. } \\
{[27]}\end{array}$ & 2021 & $\begin{array}{l}\text { Meta- } \\
\text {-analysis } \\
\text { of RCTs }\end{array}$ & $\begin{array}{l}12 \text { RCTs ( } n=503 \\
\text { individuals including } \\
\text { hypertensive pa- } \\
\text { tients) }\end{array}$ & $\begin{array}{l}\text { In the group treated with garlic: } \\
\text { - TC: reduction by } 17.17 \mathrm{mg} / \mathrm{dL}(95 \% \mathrm{Cl}:-28.57 \text { to } \\
-5.78 \mathrm{mg} / \mathrm{dL}, \mathrm{p}<0.00001)\end{array}$ & \\
\hline $\begin{array}{l}\text { Shabani et } \\
\text { al. [34] }\end{array}$ & 2019 & $\begin{array}{l}\text { Meta- } \\
\text {-analysis } \\
\text { of clinical } \\
\text { trials }\end{array}$ & $\begin{array}{l}33 \text { clinical trials } \\
\text { ( } n=1,273 \text { patients } \\
\text { with diabetes) }\end{array}$ & $\begin{array}{l}\text { In the group treated with garlic: } \\
\text { - } \quad \text { TC: reduction by } 16.87 \mathrm{mg} / \mathrm{dL}(95 \% \mathrm{Cl}:-21.01 \text { to } \\
-12.73 \mathrm{mg} / \mathrm{dL}, \mathrm{p}=0.001) \\
\text { - } \mathrm{HDL} \text { cholesterol: increase by } 3.19 \mathrm{mg} / \mathrm{dL}(95 \% \\
\text { Cl: } 1.85 \text { to } 4.53 \mathrm{mg} / \mathrm{dL}, \mathrm{p}=0.001) \\
\text { - } \mathrm{LDL} \text { cholesterol: reduction by } 9.65 \mathrm{mg} / \mathrm{dL}(95 \% \\
\text { Cl: }-15.07 \text { to }-4.23 \mathrm{mg} / \mathrm{dL}, \mathrm{p}=0.001) \\
\text { - } \quad \text { TG: reduction by } 12.44 \mathrm{mg} / \mathrm{dL}(95 \% \mathrm{Cl}:-18.19 \text { to } \\
-6.69 \mathrm{mg} / \mathrm{dL}, p=0.001)\end{array}$ & \\
\hline $\begin{array}{l}\text { Sun et al. } \\
\text { [35] }\end{array}$ & 2018 & $\begin{array}{l}\text { Meta- } \\
\text {-analysis } \\
\text { of clinical } \\
\text { trials }\end{array}$ & $\begin{array}{l}14 \text { clinical trials } \\
(\mathrm{n}=1,093 \text { patients } \\
\text { with dyslipidemia) }\end{array}$ & $\begin{array}{l}\text { In the group treated with garlic: } \\
\text { - TC: reduced concentration }(\mathrm{SMD}=\mathbf{- 1 . 2 6 , 9 5 \%} \\
\text { Cl: }-1.86 \text { to }-0.66, p<0.0001) \\
\text { - } \mathrm{LDL} \text { cholesterol: decreased concentration (SMD } \\
=-1.07,95 \% \mathrm{Cl}:-1.67 \text { to }-0.47, p<0.0001) \\
\text { - } \mathrm{HDL} \text { cholesterol: increased concentration (SMD } \\
=0.50,95 \% \mathrm{Cl}: 0.06 \text { to } 0.94, p<0.0001) \\
\text { - } \quad \text { TG: not significant }\end{array}$ & \\
\hline $\begin{array}{l}\text { Sahebkar } \\
\text { et al. [36] }\end{array}$ & 2016 & $\begin{array}{l}\text { Meta- } \\
\text {-analysis } \\
\text { of RCTs }\end{array}$ & $\begin{array}{l}6 \text { RCTs }(n=286 \\
\text { including patients } \\
\text { with dyslipidemia) }\end{array}$ & $\begin{array}{l}\text { In the group treated with garlic: } \\
\text { - lipoprotein (a): not significant }\end{array}$ & \\
\hline \multirow[t]{2}{*}{$\begin{array}{l}\text { Kwak et } \\
\text { al. [32] }\end{array}$} & 2014 & $\begin{array}{l}\text { Meta- } \\
\text {-analysis } \\
\text { of RCTs }\end{array}$ & 22/17/18 RCT & $\begin{array}{l}\text { In the group treated with garlic: } \\
\text { - } \quad \text { TC: reduction by } 15.83 \mathrm{mg} / \mathrm{dL}(95 \% \mathrm{Cl}:-26.64 \text { to } \\
-4.63 \mathrm{mg} / \mathrm{dL}, \mathrm{p}=0.005) \\
\text { - } \mathrm{LDL} \text { cholesterol: reduction by } 9.11 \mathrm{mg} / \mathrm{dL}(95 \% \\
\text { Cl: }-15.44 \text { to }-1.16 \mathrm{mg} / \mathrm{dL}, p=0.024)\end{array}$ & \\
\hline & & & & HDL cholesterol: not significant & \\
\hline \multirow[t]{4}{*}{$\begin{array}{l}\text { Reid et al. } \\
{[37]}\end{array}$} & 2013 & $\begin{array}{l}\text { Meta- } \\
\text {-analysis } \\
\text { of RCTs }\end{array}$ & $\begin{array}{l}39 \text { RCTs ( } n=2,298 \\
\text { individuals, including } \\
\text { patients with dyslipi- } \\
\text { demia) }\end{array}$ & $\begin{array}{l}\text { TC: } \\
\text { - individuals with TC } \leq 200 \mathrm{mg} / \mathrm{dL} \text { : } \text { not significant } \\
\text { reduction }(95 \% \mathrm{Cl}:-23.48 \mathrm{to}-11.16 \mathrm{mg} / \mathrm{dL} \text {, } \\
\mathrm{p}<0.00001)^{*}\end{array}$ & \\
\hline & & & & $\begin{array}{l}\text { LDL cholesterol: } \\
\text { - } \quad \text { reduction by } 6.41 \mathrm{mg} / \mathrm{dL}(95 \% \mathrm{Cl}:-11.77 \text { to } \\
01.05 \mathrm{mg} / \mathrm{dL}, p=0.02)\end{array}$ & \\
\hline & & & & $\begin{array}{l}\text { HDL cholesterol: } \\
\text { - increased by } 1.49 \mathrm{mg} / \mathrm{dL}(95 \% \mathrm{Cl}: 0.19 \text { to } 2.79 \text {, } \\
\quad p=0.02)\end{array}$ & \\
\hline & & & & TG: not significant & \\
\hline \multirow[t]{2}{*}{$\begin{array}{l}\text { Zeng et al. } \\
{[38]}\end{array}$} & 2012 & $\begin{array}{l}\text { Meta- } \\
\text {-analysis } \\
\text { of RCTs }\end{array}$ & 26 RCTs & $\begin{array}{l}\text { In the group treated with garlic: } \\
\text { - } \quad \text { TC: reduction by } 10.83 \mathrm{mg} / \mathrm{dL}(95 \% \mathrm{Cl}:-17.40 \text { to } \\
-4.25 \mathrm{mg} / \mathrm{dL}, \mathrm{p}=0.001) \\
\text { - } \quad \text { TG: reduction by } 11.51 \mathrm{mg} / \mathrm{dL}(95 \% \mathrm{Cl}:-17.71 \text { to } \\
-5.31, p<0.001)\end{array}$ & \\
\hline & & & & $\begin{array}{l}\text { The hypolipemic effect was more pronounced during } \\
\text { the longer intervention. Garlic powder and mature } \\
\text { garlic extract resulted in a greater reduction in total } \\
\text { serum cholesterol, whereas garlic oil resulted in a gre- } \\
\text { ater reduction in serum triglycerides }\end{array}$ & \\
\hline
\end{tabular}


actinomycetemcomitans and Streptococcus mutans [24, 25]. It seems that periodontitis constitutes a non-traditional risk factor for the development of hypertension [26]. The antihypertensive properties of garlic may also be related to its effect on maintaining a healthy oral microbiota.

\section{Garlic for hypertension \\ and lipid metabolism - what do results of clinical studies say?}

There are many randomized controlled trials (RCT) investigating the impact of garlic on blood pressure and lipid metabolism available in the literature. Results of these studies have been collectively summarized in numerous meta-analyses, the results of which are presented in Table 1 [23, 27-32] and Table 2 [27, 33-38].

Garlic preparations that were most used in clinical trials included garlic powder, mature garlic extract, garlic oil, Japanese garlic powder containing egg yolk, and raw garlic. Doses of individual preparations varied, as did the duration of the intervention (several weeks on average) $[23,27$, 38]. In the meta-analysis by Ried [28], it was observed that formulations containing garlic had a high safety profile and were well tolerated.

Garlic has been shown to have antihypertensive and hypolipemic properties that were particularly evident in patients with cardiovascular risk factors [23, 27-38].

A recent meta-analysis conducted by Schoeneck and Iggman [39] evaluated the hypolipemic effect of garlic. It was observed that the impact of garlic on reducing serum low-density lipoprotein (LDL) cholesterol was small to moderate (maximum reduction of its concentration by approx. $15 \mathrm{mg} / \mathrm{dL}$ ) [39].

A very interesting, randomized controlled and double-blind trial conducted by Wlosinksa et al. [40] investigated the impact of supplementation with mature garlic extract $(2,400 \mathrm{mg} /$ day for a year) on the progression of coronary artery calcification. It involved 104 patients who were randomized to receive supplementation with mature garlic extract or placebo. It was demonstrated that the applied intervention had a significant impact on reducing the progression of coronary calcification ( $p=0.040)$. In addition, glucose $(p=0.034)$ and interleukin $6(p=0.049)$ concentration as well as systolic blood pressure $(p=0.027)$ were significantly reduced in the study group [40].

In summary, garlic shows antihypertensive and hypolipemic effects, as well as anti-atherosclerotic effects.

\section{Summary}

In Poland, where 18 million people suffer from hypercholesterolemia and 11 million have hypertension, it seems that supplementing the diet with ingredients that show hypotensive, hypolipemic, and potentially anti-atherosclerotic effects would be very beneficial. In this context, the promotion of garlic as a frequent component of the diet should be considered to be cardio- and vaso-protective activity. The lipid-lowering properties of garlic have been noticed in the latest guidelines for the treatment of lipid disorders in Poland. These guidelines indicate that garlic (5-6 g/day dose) may have a mild to moderate reduction in serum LDL cholesterol (5-10\% of the baseline concentration). The recommendation for the use of garlic in patients with lipid disorders is class Ila (should be considered) and the level of evidence $A$ (data from many randomized clinical trials or meta-analyses) [41, 42].

\section{Conflict of interest}

The authors report no conflicts of interest.

\section{References}

1. Niklas A, Flotyńska A, Puch-Walczak A, et al. WOBASZ II investigators. Prevalence, awareness, treatment and control of hypertension in the adult Polish population - Multi-center National Population Health Examination Surveys - WOBASZ studies. Arch Med Sci. 2018; 14(5): 951-961, doi: 10.5114/aoms.2017.72423, indexed in Pubmed: 30154875.

2. Pająk A, Szafraniec K, Polak M, et al. WOBASZ Investigators. Changes in the prevalence, treatment, and control of hypercholesterolemia and other dyslipidemias over 10 years in Poland: the WOBASZ study. Pol Arch Med Wewn. 2016; 126(9): 642-652, doi: 10.20452/ /pamw.3464, indexed in Pubmed: 27452484.

3. Niklas A, Marcinkowska J, Kozela M, et al. Blood pressure and cholesterol control in patients with hypertension and hypercholesterolemia: the results from the Polish multicenter national health survey WOBASZ II. Pol Arch Intern Med. 2019; 129(12): 864-873, doi: 10.20452/pamw.15013, indexed in Pubmed: 31596271.

4. Surma S, Szyndler A, Narkiewicz K. Świadomość wybranych czynników ryzyka chorób układu sercowo-naczyniowego w populacji młodych osób. Choroby Serca i Naczyń. 2017; 14(4): 186-193.

5. Surma S, Szyndler A, Narkiewicz K. Świadomość nadciśnienia tętniczego i innych czynników ryzyka chorób układu sercowo-naczyniowego w populacji osób dorosłych. Choroby Serca i Naczyń. 2018; 15(1): 14-22.

6. Ndanuko RN, Tapsell LC, Charlton KE, et al. Dietary patterns and blood pressure in adults: a systematic review and meta-analysis of randomized controlled trials. Adv Nutr. 2016; 7(1): 76-89, doi: 10.3945/ /an.115.009753, indexed in Pubmed: 26773016.

7. Ge L, Sadeghirad B, Ball GDC, et al. Comparison of dietary macronutrient patterns of 14 popular named dietary programmes for weight and cardiovascular risk factor reduction in adults: systematic review and network meta-analysis of randomised trials. BMJ. 2020; 369: m696, doi: 10.1136/bmj.m696, indexed in Pubmed: 32238384.

8. Schoeneck M, Iggman D. The effects of foods on LDL cholesterol levels: a systematic review of the accumulated evidence from systematic reviews and meta-analyses of randomized controlled trials. Nutr Metab Cardiovasc Dis. 2021; 31(5): 1325-1338, doi: 10.1016/j. numecd.2020.12.032, indexed in Pubmed: 33762150.

9. Bayan L, Koulivand PH, Gorji A. Garlic: a review of potential therapeutic effects. Avicenna J Phytomed. 2014; 4(1): 1-14, indexed in Pubmed: 25050296.

10. Shang Ao, Cao SY, $\mathrm{Xu} X Y$, et al. Bioactive compounds and biological functions of garlic (Allium sativum L.). Foods. 2019; 8(7): 246, doi: 10.3390/foods8070246, indexed in Pubmed: 31284512. 
11. Ribeiro M, Alvarenga L, Cardozo LF, et al. From the distinctive smell to therapeutic effects: garlic for cardiovascular, hepatic, gut, diabetes and chronic kidney disease. Clin Nutr. 2021; 40(7): 4807-4819, doi: 10.1016/j.clnu.2021.03.005, indexed in Pubmed: 34147285.

12. Kopec A, Piatkowska E, Leszczynska T, etal. Healthy properties of garlic. Curr Nutr Food Sci. 2013; 9(1): 59-64, doi: 10.2174/157340113804810888.

13. Rybczyńska K, Gaweł-Bęben K, Surma S, Gmiński J. Wpływ ekstraktów z różnych odmian czosnku na ekspresję metaloproteaz ADAM w ludzkich komórkach śródbłonka in vitro. . In: Karkowska M, Gustaw W. ed. Trendy w żywieniu człowieka. Wydawnictwo Naukowe, Polskie Wydawnictwo Technologii Żywności, Kraków 2015: 279-287.

14. Matysiak M, Gaweł-Bęben K, Rybczyńska K, et al. [Comparing selected biological properties of garlic (Allium sativum L.) from Poland and China] [Article in Polish]. Zywnosc.Nauka.Technologia.Jakosc/Food.Science.Technology.Quality. 2015; 21(99): 160-169, doi: 10.15193/zntj/2015/99/030.

15. Matysiak M, Rybczyńska K, Gaweł-Bęben K, Surma S, Gmiński J. Antioxidant properities of garlic verieties. 5th International Young Scientists Conference „Human - Nutrition - Environment”. Abstract book. Rzeszów 2014: 207-208.

16. Gaweł-Bęben K, Surma S. Antosiewicz B. Binduga U. Wołowiec S, Gmiński J. Oblicza różnych odmian czosnku. XII Ogólnopolska Konferencja naukowa "Nowoczesne trendy w kosmetologii i dietetyce”. Książka streszczeń. Poznań 2013: 30-31.

17. Borghi C, Cicero AFG. Nutraceuticals with a clinically detectable blood pressure-lowering effect: a review of available randomized clinical trials and their meta-analyses. Br J Clin Pharmacol. 2017; 83(1): 163-171, doi: 10.1111/bcp.12902, indexed in Pubmed: 26852373.

18. Hosseini $A$, Hosseinzadeh $H$. A review on the effects of Allium sativum (garlic) in metabolic syndrome. J Endocrinol Invest. 2015;38(11): 1147-1157, doi: 10.1007/s40618-015-0313-8, indexed in Pubmed: 26036599.

19. Sobenin IA, Myasoedova VA, Iltchuk MI, et al. Therapeutic effects of garlic in cardiovascular atherosclerotic disease. Chin J Nat Med. 2019; 17(10): 721-728, doi: 10.1016/S1875-5364(19)30088-3, indexed in Pubmed: 31703752.

20. Lin MC, Wang EJ, Lee C, et al. Garlic inhibits microsomal triglyceride transfer protein gene expression in human liver and intestinal cell lines and in rat intestine. J Nutr. 2002; 132(6): 1165-1168, doi: 10.1093/jn/132.6.1165, indexed in Pubmed: 12042427.

21. Sun S, Lulla A, Sioda M, et al. Gut microbiota composition and blood pressure. Hypertension. 2019; 73(5): 998-1006, doi: 10.1161/ /HYPERTENSIONAHA.118.12109, indexed in Pubmed: 30905192.

22. Liu J, Zhang D, Guo Y, et al. The effect of Lactobacillus consumption on human blood pressure: a systematic review and meta-analysis of randomized controlled trials. Complement Ther Med. 2020; 54: 102547, doi: 10.1016/j.ctim.2020.102547, indexed in Pubmed: 33183665.

23. Ried K. Garlic lowers blood pressure in hypertensive subjects, improves arterial stiffness and gut microbiota: A review and meta-analysis. Exp Ther Med. 2020; 19(2): 1472-1478, doi: 10.3892/ /etm.2019.8374, indexed in Pubmed: 32010325.

24. Hoglund KB, Barnett BK, Watson SA, et al. Activity of bioactive garlic compounds on the oral microbiome: a literature review. Gen Dent. 2020; 68(3): 27-33, indexed in Pubmed: 32348240.

25. Bakri IM, Douglas CWI. Inhibitory effect of garlic extract on oral bacteria. Arch Oral Biol. 2005; 50(7): 645-651, doi: 10.1016/j.archoralbio.2004.12.002, indexed in Pubmed: 15892950.

26. Surma S, Romańczyk M, Witalińska-Łabuzek J, et al. Periodontitis, blood pressure, and the risk and control of arterial hypertension: epidemiological, clinical, and pathophysiological aspects - review of the literature and clinical trials. Curr Hypertens Rep. 2021; 23(5): 27 , doi: 10.1007/s11906-021-01140-x, indexed in Pubmed: 33961166.

27. Mulawarman R, Trifitriana M, Felani M, et al. 13. Garlic effect on reduce blood pressure and cholesterol in patients with and without hypertension: a systematic review and meta-analysis of randomized controlled trials. J Hypertens. 2021; 39(Suppl 2): e4, doi: 10.1097/01. hjh.0000752400.24367.fa.

28. Ried K. Garlic lowers blood pressure in hypertensive individuals, regulates serum cholesterol, and stimulates immunity: an updated meta-analysis and review. J Nutr. 2016; 146(2): 389S-396S, doi: 10.3945/jn.114.202192, indexed in Pubmed: 26764326.

29. Rohner A, Ried K, Sobenin IA, et al. A systematic review and metaanalysis on the effects of garlic preparations on blood pressure in individuals with hypertension. Am J Hypertens. 2015; 28(3): 414-423, doi: 10.1093/ajh/hpu165, indexed in Pubmed: 25239480.

30. Wang HP, Yang J, Qin LQ, et al. Effect of garlic on blood pressure: a meta-analysis. J Clin Hypertens (Greenwich). 2015; 17(3): 223-231, doi: 10.1111/jch.12473, indexed in Pubmed: 25557383.

31. Xiong XJ, Wang PQ, Li SJ, et al. Garlic for hypertension: a systematic review and meta-analysis of randomized controlled trials. Phytomedicine. 2015; 22(3): 352-361, doi: 10.1016/j.phymed.2014.12.013, indexed in Pubmed: 25837272.

32. Kwak JS, Kim JiY, Paek JuE, et al. Garlic powder intake and cardiovascular risk factors: a meta-analysis of randomized controlled clinical trials. Nutr Res Pract. 2014; 8(6): 644-654, doi: 10.4162/ /nrp.2014.8.6.644, indexed in Pubmed: 25489404.

33. Gyawali D, Vohra R, Orme-Johnson D, et al. A systematic review and meta-analysis of ayurvedic herbal preparations for hypercholesterolemia. Medicina (Kaunas). 2021; 57(6), doi: 10.3390/medicina57060546, indexed in Pubmed: 34071454.

34. Shabani E, Sayemiri K, Mohammadpour M. The effect of garlic on lipid profile and glucose parameters in diabetic patients: A systematic review and meta-analysis. Prim Care Diabetes. 2019; 13(1): 28-42, doi: 10.1016/j.pcd.2018.07.007, indexed in Pubmed: 30049636.

35. Sun YE, Wang W, Qin J. Anti-hyperlipidemia of garlic by reducing the level of total cholesterol and low-density lipoprotein: A meta-analysis. Medicine (Baltimore). 2018; 97(18): e0255, doi: 10.1097/ /MD.0000000000010255, indexed in Pubmed: 29718835.

36. Sahebkar A, Serban C, Ursoniu S, et al. Effect of garlic on plasma lipoprotein(a) concentrations: a systematic review and meta-analysis of randomized controlled clinical trials. Nutrition. 2016; 32(1): 33-40, doi: 10.1016/j.nut.2015.06.009, indexed in Pubmed: 26522661.

37. Ried K, Toben C, Fakler P. Effect of garlic on serum lipids: an updated meta-analysis. Nutr Rev. 2013; 71(5): 282-299, doi: 10.1111/ /nure.12012, indexed in Pubmed: 23590705.

38. Zeng T, Guo FF, Zhang CL, et al. A meta-analysis of randomized, double-blind, placebo-controlled trials for the effects of garlic on serum lipid profiles. J Sci Food Agric. 2012; 92(9): 1892-1902, doi: 10.1002/jsfa.5557, indexed in Pubmed: 22234974.

39. Schoeneck M, Iggman D. The effects of foods on LDL cholesterol levels: a systematic review of the accumulated evidence from systematic reviews and meta-analyses of randomized controlled trials. Nutr Metab Cardiovasc Dis. 2021; 31(5): 1325-1338, doi: 10.1016/j. numecd.2020.12.032, indexed in Pubmed: 33762150.

40. Wlosinska M, Nilsson AC, Hlebowicz J, et al. The effect of aged garlic extract on the atherosclerotic process - a randomized double-blind placebo-controlled trial. BMC Complement Med Ther. 2020; 20(1): 132, doi: 10.1186/s12906-020-02932-5, indexed in Pubmed: 32349742.

41. Szymański FM, Mickiewicz A, Dzida G, et al. Leczenie dyslipidemii w Polsce - interdyscyplinarne stanowisko grupy ekspertów wsparte przez Sekcję Farmakoterapii Sercowo-Naczyniowej Polskiego Towarzystwa Kardiologicznego. IV Deklaracja Sopocka. Choroby Serca i Naczyń. 2021, doi: 10.5603/ChSiN.2021.0011.

42. Banach M, Burchardt P, Chlebus K, et al. PoLA/CFPiP/PCS/PSLD/ /PSD/PSH guidelines on the diagnosis and tehrapy of lipid disorders in Poland. Arch Med Sci. 2021; 17(6): in press. 